\title{
Food preference by Nile rat Arvicanthis niloticus in multi choice of different cereal and legume seeds under laboratory conditions
}

\author{
Hassan, H. M. and A. F. M. Ali
}

Plant Protection Dept. Fac. of Agric. Minia Univ.

\begin{abstract}
The total consumptions from cereals whole and grinded in the $1^{\text {st }}$ day of the trial were $3.1,1.1,1.5,1.6$, and $1.9 \mathrm{~g} / 100 \mathrm{~g}$ body wt. of wheat, maize, sorghum ,rice and barely, respectively. The total intake from whole and grinded cereals in the $2^{\text {nd }}$ day exceled the intake in the $1^{\text {st }}$ day recording $3.4,1.4,1.7$ and $2.0 \mathrm{~g} / 100 \mathrm{~g}$ body wt., consecutively. The total accounted consumptions from these cereals (whole and grinded) in the $3^{\text {rd }}$ day recorded the highest amounts of 5.4, 1.6, 2.4, 2.8 and $1.6 \mathrm{~g} / 100 \mathrm{~g}$ body wt., respectively. The counted total consumptions of these foods (wheat, maize, sorghum, rice and barely) in the $4^{\text {th }}$ day were reduced than the 3rd day recording $3.9,1.8,2.1,2.5$ and $0.9 \mathrm{~g} / 100 \mathrm{~g}$ of body wt., respectively. At the $5^{\text {th }}$ day (the trial finale) the total consumed of both whole and grinded cereals reduced to be 3.2, 1.3, 1.8, 2.4 and 0.8 with wheat, maize, sorghum, rice and barely, respectively.

Total consumption of lentil, fenugreek, cowpea, broad-bean, soybean, sweet pea and groundnut (whole and grinded) in the $1^{\text {st }}$ day were $1.2,0.0,2.4,0.7,1.6,2.7$ and $3.2 \mathrm{~g} / 100 \mathrm{~g}$ body wt., respectively. In the $2^{\text {nd }}$ day the total consumed amounts of lentil, fenugreek, cowpea, broad-bean, soybean, sweet pea and groundnut in the $2^{\text {nd }}$ day were $1.6,0.0,2.3,1.1,2.1,3.1$ and $3.2 \mathrm{~g} / 100 \mathrm{~g}$ body wt., respectively. The $3^{\text {rd }}$ day recorded the highest consumed values from lentil, fenugreek, cowpea, broad-bean, soybean, sweet pea and groundnut these values were as follows 2.0, 0.0, 2.2, 1.4, 1.9, $3.2 \& 3.4 \mathrm{~g} / 100 \mathrm{~g}$ body wt., from the total (whole and grinded), respectively. The $4^{\text {th }}$ day of trial show less total consumption than that of the $3^{\text {rd }}$ day recording $1.9,0.0,2.1,1.0,1.6,3.0$ and $3.2 \mathrm{~g} / 100 \mathrm{~g}$ body wt., respectively. In the last day of the trial $\left(5^{\text {th }}\right.$ day) the intake of legume food items was in similar and didn't differ obviously than the consumption of the $4^{\text {th }}$ day recording the total intake of the whole and grinded legumes as follows 1.6, 0.0, 2.0, 1.3, 1.7, 3.0 and $3.1 \mathrm{~g} / 100 \mathrm{~g}$ body wt., respectively
\end{abstract}

Key words: Food preference, Nile rat, Arvicanthus niloticus, Cereal seeds

\section{Introduction}

Rodents are a dominant group of mammals. Most of living rodent species the Muridae, and most of rodents exist in Egypt also belong to this family. Rodents occupy a wide natural habitat; they can be found in forests, grasslands, agricultural landscapes, villages and townships. Rodents play an important role in the food web, both as consumers of plants and as food resources for many of larger predators, they also help aerating the soil through their digging and burrowing activities such as the Nile rat Arvicanthus niloticus.

The success of rodent control depends on the preference of the bait materials used. The ideal bait is the one that shows attractiveness and acceptance to many rodent species and it is easy to be prepared and to be applied ( Thompson et al, 1972; Brooks and Bowerman, 1973; Abdel-Gawad and Maher Ali, 1982; Asran et al.; El-Deeb et al, 1985; Sherief et al, 1985;l-Bahrawy, 1989; Abd El- Rahman et al, 1991; Shafi et al, 1992; Abdel-Galil, 1997; Khan et al, 2000; Witmer et al, 2008 and Desoky, 2011).

This study aims to shad light upon the preference and consumption of different cereal seed food items by the Nile rat, A. niloticus.

\section{Materials and methods}

In multi-choice feeding trials, ten food items of cereals i.e. whole wheat, grinded wheat, whole maize, grinded maize, whole rice, grinded maize whole sorghum, grinded sorghum, whole barely and grinded barely were presented simultaneously to rat. Each container attached with the multi choice unit was offered $20 \mathrm{~g}$ of each food in separate bait containers for five consecutive days. The position of the food containers was changed clockwise daily to avoid place preference by the rat. Five replicates were used. Other units were processed and supplied with seven whole legume seeds and seven for the grinded legume seeds of lentil, fenugreek, cowpea, broad-bean, soybean, sweet pea and groundnut.

The units of multi-choice trial for comparison ten food items of the cereal seeds were four circular plastic dishes attached by ten tubes and ten containers (five for the food as whole seeds and other five were for the grinded seeds of the these foods) for testing the type of food whoever preferred. Each unit served as a replicate from five replicates. Other large units attached with fourteen tubes served for the testing of legume food

\section{Results and discussion}

Data in Table (1) show the consumed in the $1^{\text {st }}$ day of the experiment from the whole and grinded cereals by Nile rat Arvicanthes niloticus under laboratory condition. The consumption from whole cereals surpassed other from grinded cereals of wheat, sorghum, rice and barely, while the opposite result was recorded with maize whereas the grinded cereals was consumed more than the whole cereals Ford (1977) found that increasing hardness of diet reduced 
food wastage by mice and rats . The recorded intake in the $1^{\text {st }}$ day of the experiment were $2.34,0.4,1.2,1.4$ and $0.6 \mathrm{~g} / 100 \mathrm{~g}$ of body wt. from whole cereals of wheat, maize, sorghum, rice and barely, while the intake from the grinded seeds of these cereals were $0.7,0.7,0.3,0.2$ and $0.3 \mathrm{~g} / 100 \mathrm{~g}$ body wt., respectively. The total consumption from cereals whole and grinded were $3.1,1.1,1.5,1.6$, and $1.9 \mathrm{~g} /$ $100 \mathrm{~g}$ body wt. of wheat, maize, sorghum ,rice and barely, respectively. These results indicate the excellence of wheat as preferred food for the Nile rat than other cereals. This result agreed with other reported by El-Deeb et al., (1985) who studied the preference and consumption of selected bait materials offered to the Nile rat, A. niloticus under field conditions in the governorate of Benni-Suef, Egypt and mentioned that wheat was the preferred one.

In the $2^{\text {nd }}$ day the intake amounts clearly increased, whereas the recorded intake amounts from the whole cereals of wheat, maize, sorghum, rice and barely were $2.5,0.6,1.4,1.7$ and $0.6 \mathrm{~g} / 100 \mathrm{~g}$ body wt., respectively. While the intake from the grinded of these cereals were $0.9,0.8,0.3,0.3,0.3 \mathrm{~g} / 100 \mathrm{~g}$ body wt. Total intake from whole and grinded cereals in the $2^{\text {nd }}$ day exceled the intake in the $1^{\text {st }}$ day recording 3.4 , $1.4,1.7$ and $2.0 \mathrm{~g} / 100 \mathrm{~g}$ body wt., consecutively (Table 2) . Continues increase in the consumption of the whole and grinded cereals so the total consumption was observed in the $3^{\text {rd }}$ day from the trial (Table 3). Consumption of 4.0, 0.2, 2.2, 2.6 and $0.6 \mathrm{~g} /$ $100 \mathrm{~g}$ body from the whole cereals of wheat, maize, sorghum, rice and barely were recorded, consecutively. As for the consumption of grinded wheat, maize, sorghum, rice and barely cereals by Nile rat at the $3^{\text {rd }}$ day were $1.4,1.4,0.2,0.2$ and $1.0 \mathrm{~g} / 100$ $\mathrm{g}$ body wt., respectively. So the total accounted consumptions from these cereals (whole and grinded) were $5.4,1.6,2.4,2.8$ and $1.6 \mathrm{~g} / 100 \mathrm{~g}$ body wt., respectively. These results emphasize the superiority of wheat as preferred food for Nile rat. These results in agreement with the results obtained by AbdelKarim (1991), who reported that the wheat grain was the most preferred food to the Nile rat, A. niloticus.

Table (4) indicate that the consumption of cereal food items in the $4^{\text {th }}$ day of trial started in reduction, whereas the amounts of the whole cereals of wheat, maize, sorghum, rice and barely were 3.0, 0.8, 1.8, 2.0 and 0.6 as well as $0.9,1.0,0.3,0.5$ and $0.3 \mathrm{~g} / 100 \mathrm{~g}$ body wt. from these cereals in grinded shape, respectively. So the counted total consumptions of these foods were 3.9, 1.8, 2.1, 2.5 and $0.9 \mathrm{~g} / 100 \mathrm{~g}$ of body wt., respectively. The consumptions of the whole cereals of wheat, maize, sorghum, rice and barely at the $5^{\text {th }}$ day (the trial finale) reduced to be 2.2 , $0.4,1.5,2.0$, and $0.6 \mathrm{~g} / 100 \mathrm{~g}$ body wt., respectively while the consumed from the grinded of these cereals were $1.0,0.9,0.3,0.4$ and $0.2 \mathrm{~g} / 100 \mathrm{~g}$ of body wt. Total consumed of both whole and grinded cereals in the $5^{\text {th }}$ day were $3.2,1.3,1.8,2.4$ and 0.8 with wheat, maize, sorghum, rice and barely, respectively. Figure
(1) illustrates the daily consumed of different cereal seed types /100 g of body weight of A. niloticus under the laboratory conditions. It was obvious that the high consumption of the cereal foods was attained in the $3^{\text {rd }}$ day in opposite to the low consumption that recorded in the 1 st day. The curve of the cereal food consumption clearly declined at the $5^{\text {th }}$ day of trial. We can distinguish three stages in this curve the $1^{\text {st }}$ low consumption, the $2^{\text {nd }}$ high consumption then the stable consumption that may be attributed to the caution of rats in the $1^{\text {st }}$ stage then increasing of food consumption resultant the feeling of assurance by rats and reparation the lesser intake in the $1^{\text {st }}$ stage. Last stable consumption rate may be due to the feeling of stability by rats.

Data in table (6) show that the legume seed consumptions by Nile rat as in the $1^{\text {st }}$ day were 1.0 , $0.0,1.0,0.2,0.6,1.0$ and 1.3 for whole seeds and 0.2 , $0.0,1.4,0.5,1.0,1.7$ and $1.9 \mathrm{~g} / 100 \mathrm{~g}$ body wt. for grinded seeds of lentil, fenugreek, cowpea, broadbean, soybean, sweet pea and groundnut, respectively. Total consumption of these legume food items (whole and grinded) were 1.2, 0.0, 2.4, 0.7, 1.6, 2.7 and $3.2 \mathrm{~g}$ $/ 100 \mathrm{~g}$ body wt., respectively. It was obvious that groundnut was the most preferable food and this result consented Abdel-Karim (1991) who found that peanut was the most preferable crop to Nile rat $A$. niloticus

In the $2^{\text {nd }}$ day the consumption amounts of the whole legumes were $1.3,0.0,1.1,0.3,0.9,1.1$ and 1.5 $\mathrm{g} / 100 \mathrm{~g}$ body wt., while the consumed from grinded seeds were $0.3,0.0,1.2,0.8,1.2,2.0$ and $1.7 \mathrm{~g} / 100 \mathrm{~g}$ body wt. So the total consumed amounts of lentil, fenugreek, cowpea, broad-bean, soybean, sweet pea and groundnut in the $2^{\text {nd }}$ day were $1.6,0.0,2.3,1.1$, 2.1, 3.1 and $3.2 \mathrm{~g} / 100 \mathrm{~g}$ body wt., respectively (Table 7). The $3^{\text {rd }}$ day consumption as shown in Table (8) recorded the highest consumed values from lentil, fenugreek, cowpea, broad-bean, soybean, sweet pea and groundnut as follows, $1.5,0.0,0.8,0.5,0.5,1.2 \&$ 1.6 from whole seeds and $0.5,0.0,1.4,0.9,1.4,2.0 \&$ 1.8 from grinded seeds and 2.0, 0.0, 2.2, 1.4, 1.9, 3.2 $\& 3.4 \mathrm{~g} / 100 \mathrm{~g}$ body wt., from the total (whole and grinded), respectively. The $4^{\text {th }}$ day of trial show less consumption than that of the $3^{\text {rd }}$ day recording 1.5, 0.0, $1.1,0.5,0.6,1.0$ and $1.3 \mathrm{~g} / 100 \mathrm{~g}$ body wt. from the whole seeds and $0.4,0.0,1.0,0.9,1.0,1.0$ and $1.9 \mathrm{~g} /$ $100 \mathrm{~g}$ body wt. from grinded seeds, so the total consumed from lentil, fenugreek, cowpea, broadbean, soybean, sweet pea and groundnut were 1.9, 0.0, $2.1,1.0,1.6,3.0$ and $3.2 \mathrm{~g} / 100 \mathrm{~g}$ body wt., respectively (Table 9$)$. In the last day of the trial ( $5^{\text {th }}$ day) the intake of legume food items was in similar and didn't differ obviously than the consumption of the $4^{\text {th }}$ day recording intake values of $1.4,0.0,1.2,0.5,0.6,1.2$ and $1.3 \mathrm{~g} / 100 \mathrm{~g}$ of body wt. from whole legumes and $0.4,0.0,0.8,1.1,1.8,1.9$ and $1.9 \mathrm{~g} / 100 \mathrm{~g}$ body wt. from the tested grinded legumes, The total intake of the whole and grinded legumes were 1.6, 0.0, 2.0, 1.3, $1.7,3.0$ and $3.1 \mathrm{~g} / 100 \mathrm{~g}$ body wt., respectively. Figure 
(2) illustrates the daily consumed of different legume seed types $/ 100 \mathrm{~g}$ of body weight of $A$. niloticus under the laboratory conditions. It was obvious that the high consumption of the legume foods was attained in the $3^{\text {rd }}$ day in opposite to the low consumption that recorded in the 1 st day. The curve of the legume food consumption clearly declined at the $5^{\text {th }}$ day of trial in similar trend with cereal foods. We can also distinguish three stages in this curve the $1^{\text {st }}$ low consumption, the $2^{\text {nd }}$ high consumption then the stable consumption that may be attributed to the caution of rats in the $1^{\text {st }}$ stage then increasing of food consumption resultant the feeling of assurance by rats and reparation the lesser intake in the $1^{\text {st }}$ stage. Last stable consumption rate may be due to the feeling of the state constancy by rats. Data illustrated in Figure (3) show general mean of the daily consumed from cereal and legume item foods during the experiment period. This Figure clear the high intake attained in the $3^{\text {rd }}$ day 13.8 from cereal and $14.1 \mathrm{~g}$ from legume than other tested days during the five days of the experiment and in $4^{\text {th }}$ or $5^{\text {th }}$ day the consumption was between 11.2 and 9.5 for cereals and between 12.8 and 12.7 for legume.

Table 1. Food preference by Arvicanthis niloticus in multi choice of different cereal seeds in the 1 st day of the test under laboratory condition.

\begin{tabular}{llllll}
\hline Food & Food type & $\begin{array}{l}\text { Mean } \\
\pm \text { S.E. }\end{array}$ & Food type & Mean \pm S.E. & Total consumed \\
\hline Wheat & Whole wheat & $2.4 \mathrm{a}$ & Grinded wheat & $0.7 \mathrm{c}$ & 3.1 \\
Maize & Whole maize & $0.4 \mathrm{e}$ & Grinded maize & $0.7 \mathrm{~b}$ & 1.1 \\
Sorghum & Whole sorghum & 1.2 & Grinded sorghum & 0.3 & 1.5 \\
Rice & Whole rice & 1.4 & Grinded rice & 0.2 & 1.6 \\
Barely & Whole barely & $0.6 \mathrm{e}$ & Grinded barely & $0.3 \mathrm{~d}$ & 0.9 \\
\hline
\end{tabular}

1, Mean of consumed food / $100 \mathrm{~g}$ of body weight

Table 2. Food preference by Arvicanthis niloticus in multi choice of different cereal seeds in the $2^{\text {nd }}$ day of the test under the laboratory condition

\begin{tabular}{llllll}
\hline Food & Food type & $\begin{array}{l}\text { Mean } \\
\pm \text { S.E. }\end{array}$ & Food type & Mean \pm S.E. & Total consumed \\
\hline Wheat & Whole wheat & $2.5 \mathrm{a}$ & Grinded wheat & $0.9 \mathrm{c}$ & 3.4 \\
Maize & Whole maize & $0.6 \mathrm{e}$ & Grinded maize & $0.8 \mathrm{~b}$ & 1.4 \\
Sorghum & Whole sorghum & 1.4 & Grinded sorghum & 0.3 & 1.7 \\
Rice & Whole rice & 1.7 & Grinded rice & 0.3 & 2.0 \\
Barely & Whole barely & $0.6 \mathrm{e}$ & Grinded barely & $0.3 \mathrm{~d}$ & 0.9 \\
\hline
\end{tabular}

1, Mean of consumed food / $100 \mathrm{~g}$ of body weight

Table 3. Food preference by Arvicanthis niloticus in multi choice of different cereal seeds in the third day of the test under laboratory condition

\begin{tabular}{llllll}
\hline Food & Food type & $\begin{array}{l}\text { Mean } \\
\pm \text { S.E. }\end{array}$ & Food type & Mean \pm S.E. & Total consumed \\
\hline Wheat & Whole wheat & $4.0 \mathrm{a}$ & Grinded wheat & $1.4 \mathrm{c}$ & 5.4 \\
Maize & Whole maize & $0.2 \mathrm{e}$ & Cracked maize & $1.4 \mathrm{~b}$ & 1.6 \\
Sorghum & Whole sorghum & 2.2 & Cracked sorghum & 0.2 & 2.4 \\
Rice & Whole rice & 2.6 & Cracked rice & 0.2 & 2.8 \\
Barely & Whole barely & $0.6 \mathrm{e}$ & Cracked barely & $1.0 \mathrm{~d}$ & 1.6 \\
\hline
\end{tabular}

1 , Mean of consumed food / $100 \mathrm{~g}$ of body weight

Table 4. Food preference by Arvicanthis niloticus in multi choice of different cereal seeds in the $4^{\text {th }}$ day of the test under laboratory condition

\begin{tabular}{llllll}
\hline Food & Food type & $\begin{array}{l}\text { Mean } \\
\pm \text { S.E. }\end{array}$ & Food type & Mean \pm S.E. & Total consumed \\
\hline Wheat & Whole wheat & $3.0 \mathrm{a}$ & Grinded wheat & $0.9 \mathrm{c}$ & 3.9 \\
Maize & Whole maize & $0.8 \mathrm{c}$ & Grinded maize & $1.0 \mathrm{~b}$ & 1.8 \\
Sorghum & Whole sorghum & $1.8 \mathrm{~b}$ & Grinded sorghum & 0.3 & 2.1 \\
Rice & Whole rice & $2.0 \mathrm{~b}$ & Grinded rice & 0.5 & 2.5 \\
Barely & Whole barely & $0.6 \mathrm{c}$ & Grinded barely & $0.3 \mathrm{~d}$ & 0.9 \\
\hline
\end{tabular}

1, Mean of consumed food / $100 \mathrm{~g}$ of body weight 
Table 5. Food preference by Arvicanthis niloticus in multi choice of different cereal seeds in the 5th day of the test under the laboratory conditions

\begin{tabular}{llllll}
\hline Food & Food type & $\begin{array}{l}\text { Mean } \\
\pm \text { S.E. }\end{array}$ & Food type & Mean \pm S.E. & Total consumed \\
\hline Wheat & Whole wheat & $2.2 \mathrm{a}$ & Grinded wheat & $1.0 \mathrm{c}$ & 3.2 \\
Maize & Whole maize & $0.4 \mathrm{e}$ & Grinded maize & $0.9 \mathrm{c}$ & 1.3 \\
Sorghum & Whole sorghum & $1.5 \mathrm{~b}$ & Grinded sorghum & $0.3 \mathrm{~d}$ & 1.8 \\
Rice & Whole rice & $2.0 \mathrm{a}$ & Grinded rice & $0.4 \mathrm{~d}$ & 2.4 \\
Barely & Whole barely & $0.6 \mathrm{c}$ & Grinded barely & $0.2 \mathrm{~d}$ & 0.8 \\
\hline
\end{tabular}

1, Mean of consumed food / $100 \mathrm{~g}$ of body weight.

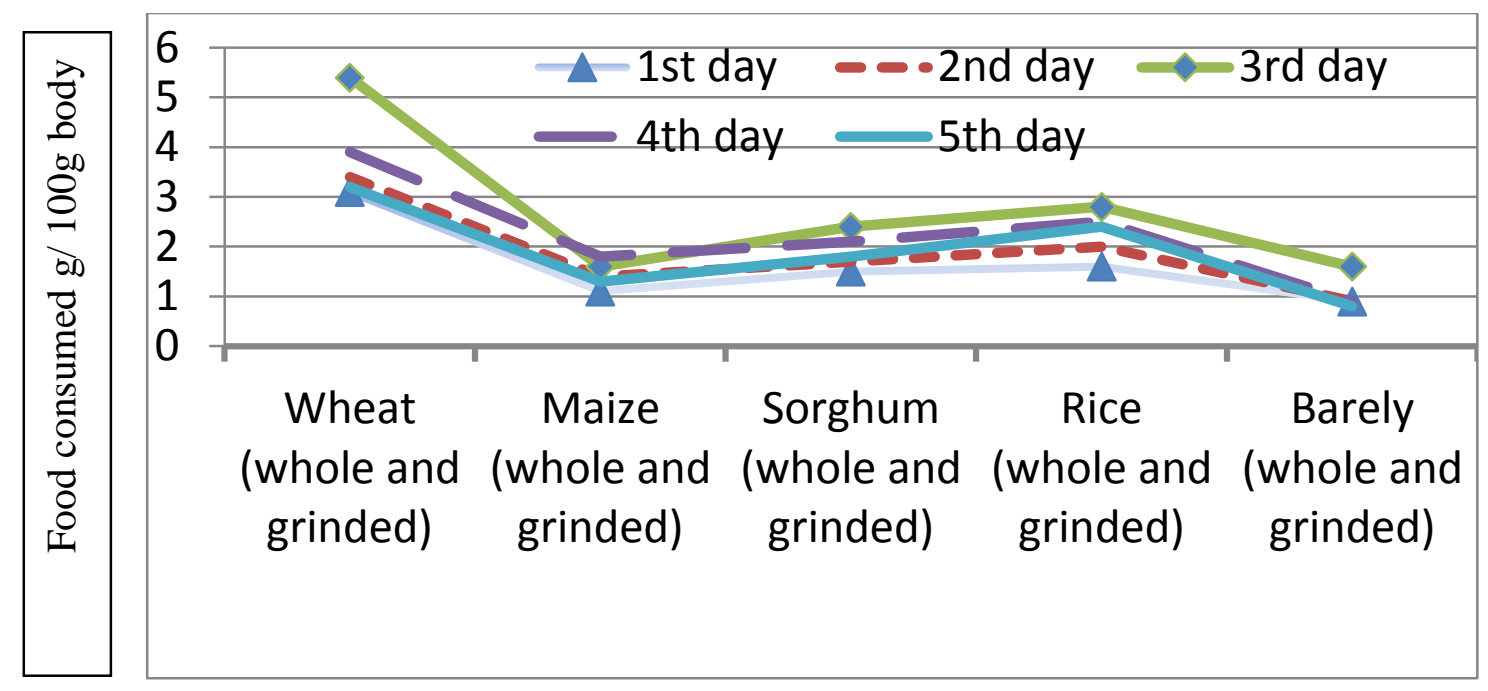

Fig. (1): Daily consumed of different cereal seed types /100 g of body weight of Arvicanthus niloticus under the laboratory conditions

Table 6. Food preference by Arvicanthis niloticus in multi choice of different legume seeds in the $1^{\text {st }}$ day of the test under laboratory condition

\begin{tabular}{llllll}
\hline Food & Food type & $\begin{array}{l}\text { Mean } \\
\mathbf{+ S . E} \mathbf{~}\end{array}$ & Food type & $\begin{array}{l}\text { Mean } \\
\mathbf{\pm S . E .}\end{array}$ & $\begin{array}{l}\text { Total } \\
\text { consumed }\end{array}$ \\
\hline Lentil & Whole lentil & 1.0 & Grinded lentil & $0.2 \mathrm{c}$ & $1.2 \mathrm{c}$ \\
Fenugreek & Whole fenugreek & 0.0 & Grinded fenugreek & $0.0 \mathrm{~b}$ & 0.0 \\
Cowpea & Whole cowpea & $1.0 \mathrm{c}$ & Grinded cowpea & 1.4 & $2.4 \mathrm{~b}$ \\
Broad-bean & Whole broad bean & 0.2 & Grinded broadbean & 0.5 & 0.7 \\
Soybean & Whole soybean & $0.6 \mathrm{e}$ & Grinded barely & $1.0 \mathrm{~d}$ & $1.6 \mathrm{bc}$ \\
$\begin{array}{l}\text { Sweet pea } \\
\text { Groundnut }\end{array}$ & Whole sweet pea & $1.0 \mathrm{c}$ & Grinded sweet pea & 1.7 & $2.7 \mathrm{ab}$ \\
\hline
\end{tabular}

Table 7. Food preference by Arvicanthis niloticus in multi choice of different legume seeds in the $2^{\text {nd }}$ day of the test under laboratory condition

\begin{tabular}{llllll}
\hline Food & Food type & $\begin{array}{l}\text { Mean } \\
\mathbf{+ S . E} \mathbf{~}^{\mathbf{n}}\end{array}$ & Food type & $\begin{array}{l}\text { Mean } \\
\mathbf{\pm S . E .}\end{array}$ & $\begin{array}{l}\text { Total } \\
\text { consumed }\end{array}$ \\
\hline Lentil & Whole lentil & $1.3 \mathrm{a}$ & Grinded lentil & $0.3 \mathrm{c}$ & $1.6 \mathrm{c}$ \\
Fenugreek & Whole fenugreek & 0.0 & Grinded fenugreek & $0.0 \mathrm{~b}$ & $0.0 \mathrm{e}$ \\
Cowpea & Whole cowpea & $1.1 \mathrm{~b}$ & Grinded cowpea & 1.2 & $2.3 \mathrm{~b}$ \\
Broad-bean & Whole broad-bean & $0.3 \mathrm{c}$ & Grinded broad-bean & 0.8 & $1.1 \mathrm{~d}$ \\
Soybean & Whole soybean & $0.9 \mathrm{~b}$ & Grinded barely & $1.2 \mathrm{~d}$ & $2.1 \mathrm{~b}$ \\
Sweet pea & Whole sweet pea & $1.1 \mathrm{ab}$ & Grinded sweet pea & $2.0 \mathrm{a}$ & $3.1 \mathrm{a}$ \\
Groundnut & Whole ground nut & $1.5 \mathrm{a}$ & Grinded groundnut & $1.7 \mathrm{~b}$ & $3.2 \mathrm{a}$ \\
\hline
\end{tabular}

${ }^{1}$ Mean of consumed food / $100 \mathrm{~g}$ of body weight 
Table 8. Food preference by Arvicanthis niloticus in multi choice of different legume seeds in the $3^{\text {rd }}$ day of the test under laboratory condition

\begin{tabular}{llllll}
\hline Food & Food type & $\begin{array}{l}\text { Mean } \\
\mathbf{+ S . E . *}\end{array}$ & Food type & $\begin{array}{l}\text { Mean } \\
\mathbf{\pm S . E} .\end{array}$ & $\begin{array}{l}\text { Total } \\
\text { consumed }\end{array}$ \\
\hline Lentil & Whole lentil & $1.5 \mathrm{a}$ & Grinded lentil & $0.5 \mathrm{~d}$ & $2.0 \mathrm{c}$ \\
Fenugreek & Whole fenugreek & $0.0 \mathrm{c}$ & Grinded fenugreek & $0.0 \mathrm{e}$ & $0.0 \mathrm{~d}$ \\
Cowpea & Whole cowpea & $0.8 \mathrm{~b}$ & Grinded cowpea & $1.4 \mathrm{~b}$ & $2.2 \mathrm{~b}$ \\
Broad-bean & Whole broad-bean & $0.5 \mathrm{~b}$ & Grinded broad-bean & $0.9 \mathrm{c}$ & $1.4 \mathrm{c}$ \\
Soybean & Whole soybean & $0.5 \mathrm{~b}$ & Grinded soybean & $1.4 \mathrm{~b}$ & $1.9 \mathrm{bc}$ \\
Sweet pea & Whole sweet pea & $1.2 \mathrm{a}$ & Grinded sweet pea & $2.0 \mathrm{a}$ & $3.2 \mathrm{a}$ \\
Groundnut & Whole ground- nut & $1.6 \mathrm{a}$ & Grinded groundnut & $1.8 \mathrm{a} \mathrm{b}$ & $3.4 \mathrm{a}$ \\
\hline
\end{tabular}

${ }^{1}$ Mean of consumed food / $100 \mathrm{~g}$ of body weight

Table 9. Food preference by Arvicanthis niloticus in multi choice of different legume seeds in the $4^{\text {th }}$ day of the test under laboratory condition

\begin{tabular}{llllll}
\hline Food & Food type & $\begin{array}{l}\text { Mean } \\
\mathbf{\pm S . E} *\end{array}$ & Food type & $\begin{array}{l}\text { Mean } \\
\mathbf{\pm S . E} .\end{array}$ & $\begin{array}{l}\text { Total } \\
\text { consumed }\end{array}$ \\
\hline Lentil & Whole lentil & $1.5 \mathrm{a}$ & Grinded lentil & $0.4 \mathrm{~d}$ & $1.9 \mathrm{c}$ \\
Fenugreek & Whole fenugreek & $0.0 \mathrm{e}$ & Grinded fenugreek & $0.0 \mathrm{e}$ & $0.0 \mathrm{e}$ \\
Cowpea & Whole cowpea & $1.1 \mathrm{~b}$ & Grinded cowpea & $1.0 \mathrm{~b}$ & $2.1 \mathrm{~b}$ \\
Broad-bean & Whole broad-bean & $0.5 \mathrm{~d}$ & Grinded broad-bean & $0.5 \mathrm{c}$ & $1.0 \mathrm{~d}$ \\
Soybean & Whole soybean & $0.6 \mathrm{c}$ & Grinded barely & $1.0 \mathrm{~b}$ & $1.6 \mathrm{~b}$ \\
Sweet pea & Whole sweet pea & $1.0 \mathrm{a}$ & Grinded sweet pea & $2.0 \mathrm{a}$ & $3.0 \mathrm{a}$ \\
Groundnut & Whole ground nut & $1.3 \mathrm{c}$ & Grinded groundnut & $1.9 \mathrm{~b}$ & $3.2 \mathrm{a}$ \\
\hline
\end{tabular}

Table 10. Food preference by Arvicanthis niloticus in multi choice of different legume seeds in the $5^{\text {th }}$ day of the test under laboratory condition

\begin{tabular}{llllll}
\hline Food & Food type & $\begin{array}{l}\text { Mean } \\
\mathbf{\pm S . E . *}\end{array}$ & Food type & Mean \pm S.E. & $\begin{array}{l}\text { Total } \\
\text { consumed }\end{array}$ \\
\hline Lentil & Whole lentil & $1.4 \mathrm{a}$ & Grinded lentil & $0.2 \mathrm{c}$ & $1.6 \mathrm{c}$ \\
Fenugreek & Whole fenugreek & $0.0 \mathrm{c}$ & Grinded fenugreek & $0.0 \mathrm{~d}$ & $0.0 \mathrm{~d}$ \\
Cowpea & Whole cowpea & $1.2 \mathrm{a}$ & Grinded cowpea & $0.8 \mathrm{~b}$ & $2.0 \mathrm{~b}$ \\
Broad-bean & Whole broad-bean & $0.5 \mathrm{~b}$ & Grinded broad-bean & $0.8 \mathrm{~b}$ & $1.3 \mathrm{c}$ \\
Soybean & Whole soybean & $0.6 \mathrm{~b}$ & Grinded barely & $1.1 \mathrm{~b}$ & $1.7 \mathrm{c}$ \\
Sweet pea & Whole sweet pea & $1.2 \mathrm{a}$ & Grinded sweet pea & $1.8 \mathrm{a}$ & $3.0 \mathrm{a}$ \\
Groundnut & Whole groundnut & $1.2 \mathrm{a}$ & Grinded groundnut & $1.9 \mathrm{a}$ & $3.1 \mathrm{a}$ \\
\hline
\end{tabular}

${ }^{1}$ Mean of consumed food / $100 \mathrm{~g}$ of body weight 


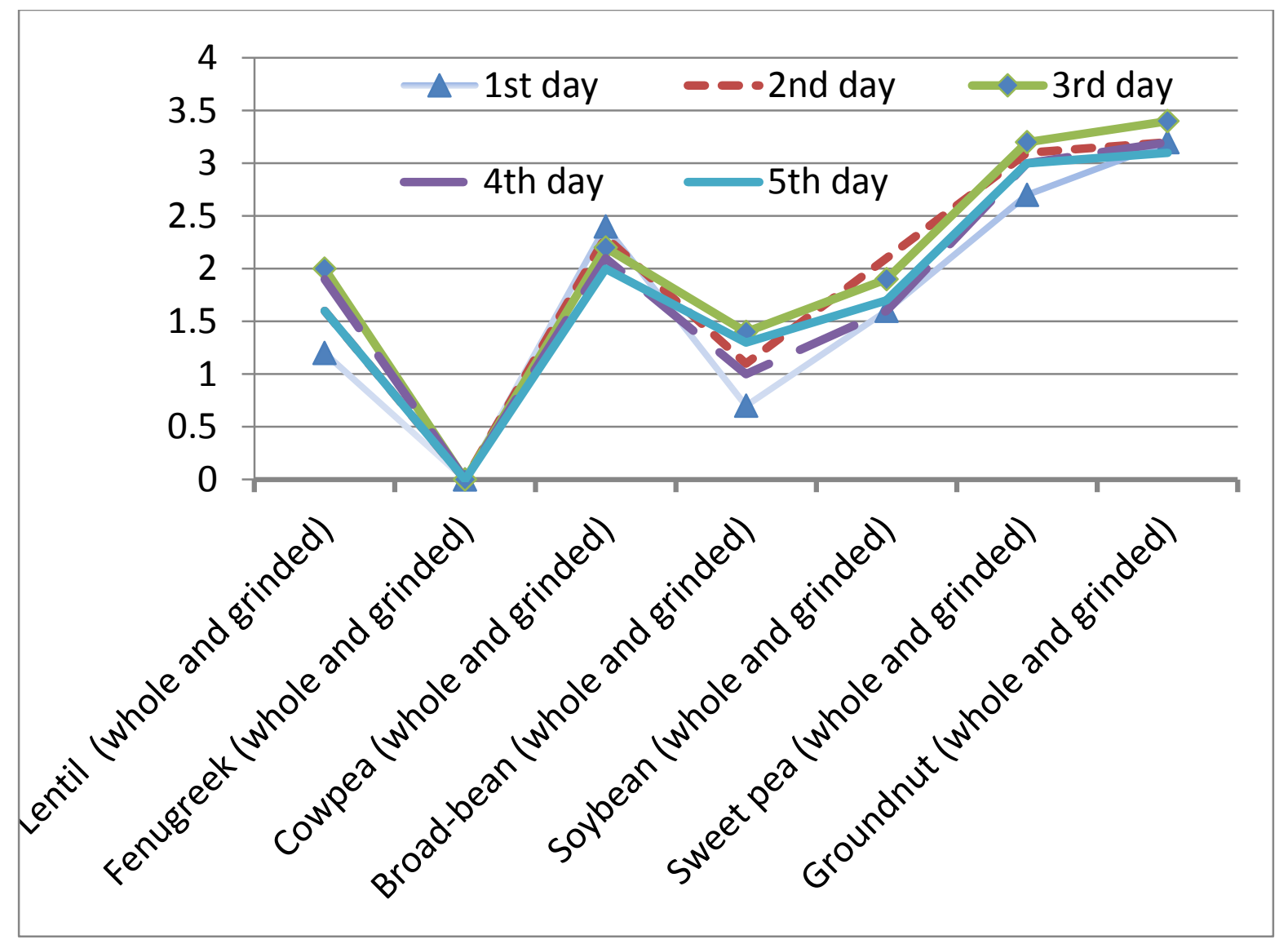

Fig. (2): Daily consumed of different cereal seed types /100 g of body weight of Arvicanthus niloticus under the laboratory conditions

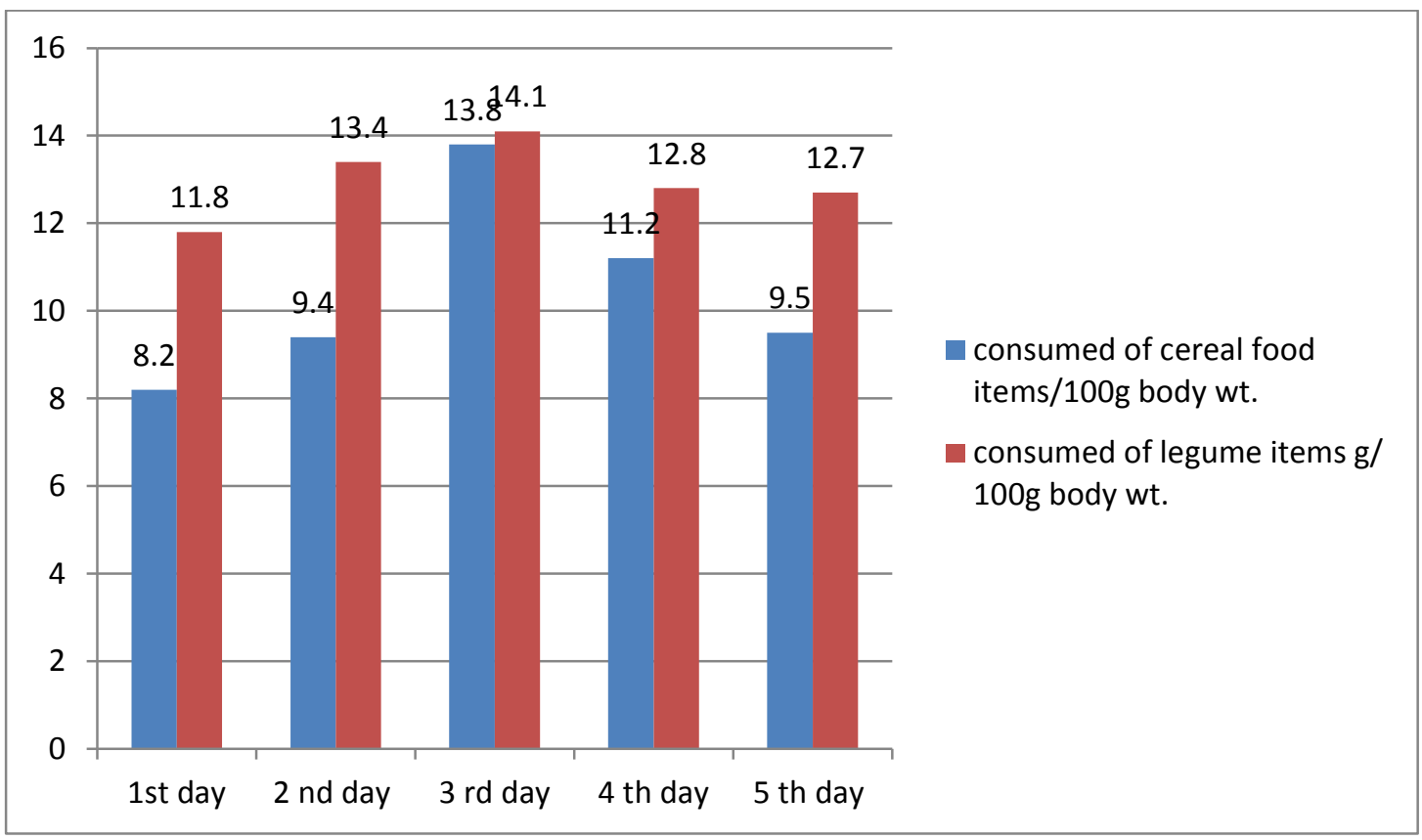

Fig. 3. General mean of the daily consumed from cereal and legume item foods during the experiment period. 


\section{References}

Abdel-Karim, S.H. (1991): Studies on rodents in Sharkia governorate. Ph. D. Thesis, Fac. Agric., Zagazig Univ. Egypt. pp. 294.

Abd El-Rahman, A.; A. Metwally and M. E. ElNaggar (1991) :Rat acceptance of non-toxic baits in Ryan Qatar State. Egypt J. Agric. Res.,69 (1): 257-261.

Abdel-Galil, Y. M.A. (1997) : Food preference studies on some rodent species infesting agricultural crops. M. Sc. Thesis, Fac. Agric., AlAzhar Univ., Egypt. pp. 143.

Abdel-Gawad, K. H. and Maher Ali, A. (1982): Food preference and food consumption of various rodent species. Assiut Journal of Agricultural Science, 13(2): 13 - 17.

Asran, A.A.; El-Deeb, H.I.; Kuehnert, G. and ElHalfawy, M.A. (1985) : Laboratory studies on the preference of certain species of rats to crushed maize bait with and without cotton seed oil. J. Agric. Sci., Mansoura Univ., Egypt, 10(2): 263264.

Brooks, J.E. and Bowerman, A.M. (1973) : Preferences of wild Norway rats for grains, seeds and legumes. Pest Control 41: 13-39.

Desoky, A. S.S. (2011): Studies on certain ectoparasites associated with some farm animals and their control. Ph. D. Thesis, Fac. Agric. Assiut Univ. 179 pp.

El-Bahrawy, A.A.F. (1989) : Food preference and food consumption of four commensal and wild rodent species under laboratory conditions. $3^{\text {rd }}$ Nat.
Conf. of Pests and Dis. of Veg. and Fruits in Egypt and Arab Count., Ismailia, Egypt: 966-974.

El-Deeb, H.I; Asran, A.A.; Kuehnert, G. and ElHalfawy, M.A. (1985) : Bait preference and bait consumption of the Nile rat, Arvicanthis niloticus. Zagazig J. Agric. Res., 12(1): 545-552.

Ford, D.J. (1977). Influence of diet pellet hardness and particle size on food utilization by mice, rats and hamsters. Laboratory Animals (London) 11: 241-246.

Khan, H. H.; Sohail, A. and Yazdan, R. (2000). Significance of additives to enhance poison baits acceptance against field rats in rice paddy in Central Punjab, Pakistan . Int. J. Agri. Biol., Vol. 2, No. 1-2.

Shafi, M. M.; S. M. Ahmed; A. Pervez and S. Ahmad (1992): Enhancement of poison bait acceptance through taste additives in Rattus norvegicus. Journal of Stored Products Research, 28 (4): 239-243.

Sherief, R.M.; Amir, M.M.I.; El-Fishawi, A.A. and Lokma, H.E. (1985): A food preference and rates of consumption in different commensal rodent species. J. Agric. Sci. Mansoura Univ., (1): 239242.

Thompson, R. D.; Shumake, S. A.; and Bullard, R. W. (1972): Methodology for measuring taste and odor preference of rodents. Proceedings of the 5th Vertebrate Pest Conference (1972). p. 9.

Witmer, G.; P. Burke and S. Jojola (2008): An Evaluation of the Effectiveness of Potential Norway Rat Attractants. Proc. 23rd Vertebr. Pest Cont. (R. M. $11 \mathrm{~mm}$ and M. B. Madon, Eds.) Published at Univ. of Calif., Davis. pp. 35-38. 